\title{
PENGARUH JENIS MULSA DAN APLIKASI PUPUK ORGANIK CAIR TERHADAP PERTUMBUHAN DAN HASIL TANAMAN KENTANG (Solanum tuberosum L.)
}

\section{EFFECT OF THE TYPE OF MULCH AND THE APPLICATION OF LIQUID ORGANIC FERTILIZERS ON THE GROWTH AND YIELD OF POTATO CROPS}

\author{
Ismadi $^{{ }^{*}}$, Nurul Indri Yani ${ }^{1}$, Hafifah $^{1}{ }^{,}$Rosnina $^{1}$ dan M. Nazaruddin ${ }^{1}$, \\ ${ }^{1}$ Program Studi Agroekoteknologi Fakultas Pertanian Universitas Malikussaleh Kampus Reuleut \\ Aceh Utara, Aceh, Indonesia \\ *Corresponding author : Ismadi@unimal.ac.id
}

\begin{abstract}
ABSTRAK
Tanaman kentang merupakan salah satu komoditi hortikultura yang berpotensi dikembangkan karena dapat karena memiliki protein, vitamin dan mineral yang tinggi serta mempunyai peran yang penting bagi perekonomian indonesia. Tanaman kentang merupaka tanaman sayuran berumur pendek. Penelitian ini bertujuan untuk mengetahui pengaruh jenis mulsa dan aplikasi pupuk organik cair terhadap pertumbuhan dan hasil tanaman kentang. Penelitian ini dilaksanakan di desa Ujung Gele Kecamatan Bukit Kabupaten Bener Meriah dengan ketinggian tempat 1300 mdpl. Penelitian ini dilaksanakan mulai Juli sampai November 2020. Penelitian ini menggunakan rancangan acak kelompok (RAK) faktorial dengan dua faktor. Faktor pertama adalah jenis mulsa yang terdiri atas tiga taraf yaitu tanpa mulsa (M1), mulsa plastik hitam perak (M2), dan mulsa kulit biji kopi (M3). Fakotr kedua adalah pupuk organik cair yang terdiri atas tiga taraf yaitu kontrol (P0), $4 \mathrm{ml} / 1$ air (P1), dan $8 \mathrm{ml} / 1$ air (P2). Peubah yang diamati adalah tinggi tanaman, jumlah daun, jumlah batang, jumlah umbi per sampel, jumlah umbi per plot, berat umbi per sampel, dan berat umbi per plot. Hasil penelitian menunjukkan bahwa pada perlakuan jenis mulsa hasil terbaik diperoleh dari penggunaan mulsa plastik hitam perak dan perlakuan terbaik pupuk organik cair adalah pada konsentrasi $8 \mathrm{ml} / 1$ air. Tidak didapati interaksi antara perlakuan jenis mulsa dan pupuk organik cair terhadap semua peubah yang diamati.
\end{abstract}

Kata kunci; granola, umbi, batang, daun

\begin{abstract}
Potatoes (Solanum tuberosum L.) is a potential commodity with a high source of carbohydrates, protein, vitamins, and minerals that play an important role in the national economy. This crop is an annual plant. The study aimed at investigating the effect of mulch types and liquid organic fertilizer on the growth and yield of potatoes. The study was conducted in Ujung Gele Villages, Bukit District, Bener Meriah Regency at 1300 masl in July to November 2020, using Randomized Block Design (RBD) factorial with two factors. The first factor was three different types of mulch: no mulch (M1), silver black plastic mulch (M2), and cocoa shell
\end{abstract}


mulch (M3). The second factor was liquid organic fertilizer concentrations; control (P0), $4 \mathrm{ml} / 1$ water $(\mathrm{P} 1)$, and $8 \mathrm{ml} / 1$ water $(\mathrm{P} 2)$. The variables observed were plant height, leaf number, number of stems, tuber number per sample, tuber number per plot, tuber weight per sample, and tuber number per plot. The results indicated that the application of silver black plastic mulch and $8 \mathrm{ml} / 1$ water liquid organic fertilizer was found to be the best. However, the interaction between mulch types and liquid organic fertilizer had no significant effect on variables observed

Keywords; granola, tuber, leaf, stem

\section{PENDAHULUAN}

Kentang (Solanum tuberosum L.) merupakan komoditas hortikultura yang menjadi bahan pangan sehingga mempunyai peran penting bagi perekonomian Indonesia. Sentra budidaya kentang di Indonesia adalah Berastagi, Toraja, Dieng, Lembang dan Tengger. Sentra produksi kentang Aceh adalah Tanah Tinggi Gayo, yakni Kabupaten Bener Meriah dan Aceh Tengah.

Jumlah produksi kentang nasional saat ini hanya sebesar 1.314 .65 ton dengan luas tanam 68.223 ha dan produktivitas sebesar 19,27 ton/ha (Kementerian Pertanian $\underline{\mathrm{RI}}$, 2020). Produksi tanaman kentang tersebut belum dapat memenuhi kebutuhan dalam negeri Indonesia. Jumlah penduduk Indonesia saat ini berjumlah 270,20 juta jiwa (http://bps.go.id, 2021) dengan tingkat konsumsi kentang sebesar 2,82 $\mathrm{kg} / \mathrm{kapita} /$ tahun (Setjen Pertanian, 2019) maka kebutuhan kentang Indonesia adalah 6.160.560 ton/tahun. Guna memenuhi kebutuhan kentang dalam negeri maka perlu ada usaha untuk meningkatkan poduksi dan produktivitas kentang di Indonesia.

Produktivitas yang rendah dapat disebabkan oleh beberapa faktor seperti penggunaan pupuk anorganik secara terus menerus sehingga menimbulkan dampak negatif terhadap lahan kentang yakni berkurang tingkat produktivitas akan menurun. Penggunaan pupuk anorganik ini menyebabkan tanah menjadi lebih cepat mengeras, kurang mampu menyimpan air, dan juga cepat menjadi asam yang pada akhirnya akan menurunkan produktivitas tanaman yang ditanam pada lahan tersebut. Cara yang dapat dilakukan untuk meningkatkan produktivitas pada lahan tersebut adalah dengan perlakuan pupuk organik.

Pupuk ornanik yang dapat digunakan pada budidaya tananam ada yang berbentuk padat dan cair yang dikenal dengan pupuk organik cair (POC). POC dapat memperbaiki sifat fisik, kimia dan biologi tanah, membantu meningkatkan produktivitas tanaman sehingga dapat mengurangi kebutuhan pupuk anorganik. Penggunaan POC $4 \mathrm{ml} / \mathrm{l}$ dapat meningkatkan jumlah daun, diameter umbi, berat basah tanaman dan berat basah umbi kentang (Parman, 2007).

Kentang adalah jenis tanaman yang tidak dapat beradaptasi pada suhu udara tinggi sehingga dapat menyebabkan produktivitas umbi kentang menurun. Suhu udara yang dibutuhkan adalah antara $30^{\circ} \mathrm{C}$ $15^{\circ} \mathrm{C}$ (Asandhi, 2006). Salah satu cara mengatasi masalah tersebut adalah dengan menggunakan mulsa pada saat budidaya. Mulsa dapat memberikan keuntungan pada tanaman baik dari aspek biologi, fisik dan kimia tanah. Penggunaan mulsa dapat menjaga suhu tanah, memperbaiki tata udara tanah, ketersediaan air menjadi lebih terjamin (Doring et al., 2006).

Jenis mulsa yang dapat digunakan adalah mulsa plastik hitam perak dan mulsa 
Jurnal Agrium

online version: https://ojs.unimal.ac.id/index.php/agrium P-ISSN 1829-9288. E-ISSN 2655-1837

organik. Mulsa organik merupakan mulsa yang berasal dari sampah atau sisa pertanian seperti eceng gondok, serbuk gergaji, dan juga kulit biji kopi (Triyanto, 2000). Mulsa organik memiliki konduktivitas panas yang rendah sehingga panas yang sampai ke permukaan tanah akan lebih sedikit dibandingkan tanpa penggunaan mulsa (Mahmood et al., 2002). Jenis mulsa organik yang digunakan pada penelitian ini adalah mulsa kulit biji kopi. kulit biji kopi merupakan produk samping dari pengolahan buah kopi yang saat ini belum dimanfaatkan secara optimal (Diniyah et al., 2013). Kulit biji kopi saat ini tersedia sangat banyak di Aceh, khususnya di Kabupaten Aceh Tengah dan Bener. Kedua kabupaten tersebut merupakan daerah sentra kopi arabika dan merupakan potensi lokal yang sangat banyak di Aceh. Penggunaan kulit biji kopi sebagai mulsa dapat memberikan keuntungan seperti meningkatkan kesuburan tanah, menghambat pertumbuhan gulma dan juga mengurangi pencemaran lingkungan. Kulit biji kopi mengandung kadar C-organik sebesar 4,53\%, nitrogen sebesar 2,98\%, fosfor $0,18 \%$, kalium 2,26\%, dan juga mengandung unsur hara $\mathrm{Ca}, \mathrm{Mg}, \mathrm{Mn}, \mathrm{Fe}, \mathrm{Cu}$ dan Zn (Dirjen Perkebunan, 2006).

\section{METODE PENELITIAN}

Penelitian ini bertempat di Desa Ujung Gele Kecamatan Bukit Kabupaten Bener Meriah dengan ketinggian tempat 1300 mdpl. Penelitian dilaksanakan dari Juli sampai November 2020. Alat-alat yang digunakan adalah sprayer, cangkul, garu, selang, meteran, timbangan analitik, penggaris, dan kamera digital. Bahan yang digukanakan adalah mulsa plastik hitam perak, mulsa kulit biji kopi, umbi bibit kentang varietas granola G2, pupuk organik
Maret, 2021

Vol. 18, Nol

Hal. 80-87

Author(s): Ismadi, et al

cair (POC) NASA, pupuk kandang sapi, pestisida ingrofol, megathane, yasithrin dan matador.

Penelitian ini menggunakan Rancangan Acak Kelompok (RAK) pola faktorial dengan dua faktor perlakuan yaitu jenis mulsa dan pupuk organik cair (POC). Faktor pertama terdiri atas tiga taraf yaitu M1 = tanpa mulsa, M2 = mulsa plastik hitam perak, dan M3 = mulsa kulit biji kopi. Faktor kedua terdiri atas tiga taraf yaitu $\mathrm{P} 0=$ $0 \mathrm{ml} / \mathrm{l}$ air POC (kontrol), $\mathrm{P} 1=4 \mathrm{ml} / \mathrm{l}$ air $\mathrm{POC}$, dan $\mathrm{P} 2=8 \mathrm{ml} / \mathrm{l}$ air POC (P2). Penelitian ini terdiri atas 9 kombinasi perlakuan dengan 3 ulangan sehingga terdapat 27 unit percobaan. Data pengamatan dianalisis secara statistik dengan uji $\mathrm{F}$ dan uji lanjut menggunakan Dunca's Multiple Rang Test (DMRT) pada taraf 5\%.

\section{HASIL DAN PEMBAHASAN Hasil}

\section{Tinggi Tanaman}

Hasil penelitian menunjukkan bahwa jenis mulsa berpengaruh terhadap tinggi tanaman kentang pada 3 dan 9 minggu setelah tanam (MST). Perlakuan konsentrasi POC tidak berpengaruh terhadap peubah tinggi tanaman kentang. Tinggi tanaman kentang di akhir pengamatan yakni pada 9 MST menunjukkan pertumbuhan tertinggi yang didapati pada perlakuan MPHP dan terendah didapati pada perlakuan mulsa biji kopi. Perlakuan pupuk organik cair dengan konsentrasi yang berbeda tidak memberikan pengaruh peubah tinggi tanaman kentang. Rata-rata tinggi tanaman kentang karena perlakuan jenis mulsa dan organik cair ditampilkan pada Tabel 1. 
Tabel 1. Rata-rata tinggi tanaman akibat perlakuan jenis mulsa dan pupuk organik cair pada tanaman Kentang.

\begin{tabular}{|c|c|c|c|c|}
\hline \multirow{2}{*}{ Perlakuan } & \multicolumn{4}{|c|}{ Umur Tanaman $(\mathrm{cm})$} \\
\hline & $3 \mathrm{MST}$ & $5 \mathrm{MST}$ & $7 \mathrm{MST}$ & $9 \mathrm{MST}$ \\
\hline \multicolumn{5}{|l|}{ Mulsa (M) } \\
\hline Tanpa Mulsa (M1) & $4,94 b$ & $14,05 \mathrm{a}$ & $20,22 \mathrm{a}$ & $20,27 \mathrm{a}$ \\
\hline MPHP (M2) & $7,11 \mathrm{a}$ & $16,11 \mathrm{a}$ & $21,77 \mathrm{a}$ & $22,44 \mathrm{a}$ \\
\hline Mulsa Kulit Biji Kopi (M3) & $5,16 \mathrm{~b}$ & $14,55 \mathrm{a}$ & $19,00 \mathrm{a}$ & $19,55 b$ \\
\hline \multicolumn{5}{|l|}{ Pupuk Organik Cair (P) } \\
\hline Kontrol (P0) & 5,66 a & $15,33 \mathrm{a}$ & $19,55 \mathrm{a}$ & $19,55 \mathrm{a}$ \\
\hline POC 4 ml/1 air (P1) & $5,88 \mathrm{a}$ & $14,77 \mathrm{a}$ & $19,94 a$ & $20,94 \mathrm{a}$ \\
\hline POC $8 \mathrm{ml} / 1$ air $(\mathrm{P} 2)$ & $5,66 \mathrm{a}$ & $14,61 \mathrm{a}$ & $21,50 \mathrm{a}$ & $21,77 \mathrm{a}$ \\
\hline
\end{tabular}

Keterangan : Angka-angka yang diikuti oleh huruf yang sama pada kolom yang sama tidak berbeda nyata berdasarkan uji DMRT pada taraf 5\%.

\section{Jumlah Daun}

Tabel 2 menunjukkan rata-rata jumlah daun akibat perlakuan jenis mulsa dan pupuk organik cair pada tanaman kentang. Perlakuan jenis mulsa dan konsentrasi POC yang berbeda tidak berpengaruh terhadap jumlah daun tanaman kentang. Namun perlakuan MPHP pada tanaman kentang cendrung memiliki daun yang lebih banyak dibandingkan dengan tanpa mulsa dan mulsa organik kulit biji kopi. Perlakuan konsentrasi $8 \mathrm{ml} / \mathrm{l}$ air memiliki kecendrungan jumlah daun tanaman kentang yang lebih banyak dibandingkan konsentrasi yang lain.

Tabel 2. Rata-rata jumlah daun akibat perlakuan jenis mulsa dan pupuk organik cair pada tanaman kentang.

\begin{tabular}{lcccc}
\hline \multirow{2}{*}{ Perlakuan } & \multicolumn{4}{c}{ Jumlah Daun (helai) } \\
\cline { 2 - 5 } & 3 MST & 5 MST & 7 MST & 9 MST \\
Mulsa (M) & 19,22(4,38)a & $33,38(5,77) \mathrm{a}$ & $37,88(6,10) \mathrm{a}$ & $38,77(6,17) \mathrm{a}$ \\
MPnpa Mulsa (M1) & $23,38(4,85) \mathrm{a}$ & $37,83(6,16) \mathrm{a}$ & $42,11(6,51) \mathrm{a}$ & $43,61(6,62) \mathrm{a}$ \\
Mulsa Kulit Biji Kopi (M3) & $20,11(4,51) \mathrm{a}$ & $30,94(5,58) \mathrm{a}$ & $38,61(6,20) \mathrm{a}$ & $39,72(6,29) \mathrm{a}$ \\
\hline Pupuk Organik Cair (P) & & & & $39,61(6,24) \mathrm{a}$ \\
Kontrol (P0) & $19,77(4,46) \mathrm{a}$ & $34,66(5,58) \mathrm{a}$ & $37,27(6,06) \mathrm{a}$ & $40,88(6,40) \mathrm{a}$ \\
POC 4 m1/1 air (P1) & $22,00(4,71) \mathrm{a}$ & $34,88(5,91) \mathrm{a}$ & $40,16(6,35) \mathrm{a}$ & $41,61(6,44) \mathrm{a}$ \\
POC 8 m1/1 air (P2) & $20,94(4,58) \mathrm{a}$ & $33,05(5,73) \mathrm{a}$ & $41,61(6,40) \mathrm{a}$ & \\
\hline
\end{tabular}

Keterangan : Angka-angka yang diikuti oleh huruf yang sama pada kolom yang sama tidak berbeda nyata berdasarkan uji DMRT pada taraf 5\%. Angka dalam kurung adalah hasil transformasi data dengan menggunakan rumus $=\sqrt{ } \mathrm{X}+0,5$. 
Jurnal Agrium

online version: https://ojs.unimal.ac.id/index.php/agrium P-ISSN 1829-9288. E-ISSN 2655-1837

\section{Jumlah Batang}

Tabel 3 menunjukkan rata-rata jumlah daun batang akibat perlakuan jenis mulsa dan pupuk organik cair pada tanaman kentang. Perlakuan jenis mulsa dan konsentrasi POC yang berbeda tidak berpengaruh terhadap jumlah batang tanaman kentang. Namun pada kontrol

Tabel 3. Rata-rata jumlah batang akibat perlakuan jenis mulsa dan pupuk organik cair pada tanaman kentang.

\begin{tabular}{|c|c|c|c|c|}
\hline \multirow{2}{*}{ Perlakuan } & \multicolumn{4}{|c|}{ Jumlah Batang Perumpun } \\
\hline & $3 \mathrm{MST}$ & $5 \mathrm{MST}$ & $7 \mathrm{MST}$ & $9 \mathrm{MST}$ \\
\hline \multicolumn{5}{|l|}{ Mulsa (M) } \\
\hline Tanpa Mulsa (M1) & $3,66(2,01) \mathrm{a}$ & $4,05(2,09) \mathrm{a}$ & $4,33(2,15) \mathrm{a}$ & $4,33(2,15) \mathrm{a}$ \\
\hline MPHP (M2) & $3,50(1,98) \mathrm{a}$ & $3,55(1,98) a$ & $3,61(2,00) \mathrm{a}$ & $3,61(2,00) \mathrm{a}$ \\
\hline Mulsa Kulit Biji Kopi (M3) & $3,44(1,97) \mathrm{a}$ & $3,50(1,98) a$ & $3,55(2,00) \mathrm{a}$ & $3,55(2,00) \mathrm{a}$ \\
\hline \multicolumn{5}{|l|}{ Pupuk Organik Cair (P) } \\
\hline Kontrol (P0) & $3,22(1,90) \mathrm{a}$ & $3,72(2,01) \mathrm{a}$ & $3,72(2,02) \mathrm{a}$ & $3,72(2,02) \mathrm{a}$ \\
\hline POC 4 ml/l air (P1) & $3,83(2,06) \mathrm{a}$ & $3,77(2,05) \mathrm{a}$ & $4,05(2,11) \mathrm{a}$ & $4,05(2,11) \mathrm{a}$ \\
\hline POC 8 ml/1 air (P2) & $3,55(1,98) a$ & $3,61(2,00) a$ & $3,72(2,02) \mathrm{a}$ & $3,72(2,02) \mathrm{a}$ \\
\hline
\end{tabular}

Keterangan : Angka-angka yang diikuti oleh huruf yang sama pada kolom yang sama tidak berbeda nyata berdasarkan uji DMRT pada taraf 5\%. Angka dalam kurung adalah hasil transformasi data dengan menggunakan rumus $=\sqrt{ } \mathrm{X}+0,5$.

\section{Jumlah dan Berat Umbi}

Berdasarkan data pada Tabel 4 menunjukkan bahwa jumlah umbi per sampel tidak berbeda nyata pada perlakuan jenis mulsa, namun berbeda nyata pada perlakuan konsentrasi POC. Perlakuan mulsa menghasilkan jumlah umbi yang sama antar berbagai jenis mulsa. Perlakuan POC menghasilkan perbedaan yang nyata antar konsentrasi. Konsentarsi POC $8 \mathrm{ml} / 1$ air menghasilkan jumlah umbi per sampel terbanyak yang mencapai 7,75 umbi.

Perlakuan jenis mulsa dan konsentrasi POC memberikan pengaruh nyata pada pengamatan jumlah umbi/plot. Perlakuan jenis mulsa MPHP menghasilkan jumlah umbi terbanyak per plot dibandingkan dengan perlakuan lainnya. Jumlah umbi yang dihasilkan mencapai 37,55 umbi sedangkan tanpa perlakuan
Maret, 2021

Vol. 18, Nol

Hal. 80-87

Author(s): Ismadi, et al

(tanpa mulsa), tanaman kentang cendrung memiliki batang yang lebih banyak dibandingkan dengan perlakuan lainnya. Perlakuan konsentrasi $4 \mathrm{ml} / \mathrm{l}$ air memiliki kecendrungan jumlah batang yang lebih banyak dibandingkan konsentrasi $8 \mathrm{ml} / \mathrm{l}$ air dan kontrol. mulsa hanya menghasilkan 27 umbi per plot. Pada perlakuan POC didapati bahwa konsentrasi $8 \mathrm{~m} / \mathrm{l}$ menghasilkan jumlah umbi terbanyak, yakni 40,11 umbi per plot, sedangkan perlakuan POC $0 \mathrm{ml} / 1$ air hanya menghasilkan 28,4 umbi per plot.

Peubah berat umbi/sampel dapati bahwa perlakuan jenis mulsa dan konsentrasi POC yang berbeda memerikan pengaruh yang nyata. Pada perlakuan jenis mulsa, umbi terberat didapati pada perlakuan jenis mulsa MPHP yang mencapai $216,83 \mathrm{~g}$, dan yang terendah pada perlakuan kontrol (tanpa mulsa). Perlakuan POC 8 ml/1 air menghasilkan berat umbi tertinggi yakni mencapai 199,06 g.

Peubah berat umbi/plot diketahui terdapat perbedaan nyata pada perlakuan jenis mulsa dan tidak berbeda nyata pada perlakuan jenis konsentrasi POC. Berat 
Jurnal Agrium

online version: https://ojs.unimal.ac.id/index.php/agrium P-ISSN 1829-9288. E-ISSN 2655-1837
Maret, 2021

Vol. 18, No1

Hal. 80-87

Author(s): Ismadi, et al umbi/plot tertinggi didapati pada perlakuan jenis mulsa MPHP dan terandah pada perlakuan tanpa mulsa. Namun perlakuan jenis mulasa MPHP tidak berbeda dengan perlakuan mulsa kulit biji kopi.

Tabel 4. Rata-rata jumlah dan berat umbi tanaman kentang akibat perlakuan jenis mulsa dan pupuk organik cair pada tanaman kentang.

\begin{tabular}{lcccc}
\hline \multicolumn{1}{c}{ Perlakuan } & $\begin{array}{c}\text { Jumlah Umbi/ } \\
\text { Sampel }\end{array}$ & $\begin{array}{c}\text { Jumlah Umbi/ } \\
\text { Plot }\end{array}$ & $\begin{array}{c}\text { Berat Umbi/ } \\
\text { Sampel }(\mathrm{g})\end{array}$ & $\begin{array}{c}\text { Berat Umbi/ } \\
\text { Plot (g) }\end{array}$ \\
\hline Mulsa (M) & & & & \\
Tanpa Mulsa (M1) & $3,88(2,08) \mathrm{a}$ & $27,00 \mathrm{~b}$ & $117,39 \mathrm{~b}$ & $863,1 \mathrm{c}$ \\
MPHP (M2) & $4,61(2,21) \mathrm{a}$ & $37,55 \mathrm{a}$ & $216,83 \mathrm{a}$ & $1651,0 \mathrm{a}$ \\
Mulsa Kulit Biji Kopi (M3) & $4,50(2,17) \mathrm{a}$ & $33,22 \mathrm{a}$ & $153,67 \mathrm{~b}$ & $1110,6 \mathrm{~b}$ \\
\hline Pupuk Organik Cair (P) & & & & $1135,0 \mathrm{a}$ \\
Kontrol (P0) & $3,44(1,97) \mathrm{b}$ & $28,4 \mathrm{~b}$ & $148,33 \mathrm{~b}$ & $1162,4 \mathrm{a}$ \\
POC 4 ml/1 air (P1) & $3,83(2,04) \mathrm{b}$ & $29,22 \mathrm{~b}$ & $140,50 \mathrm{~b}$ & $1327,2 \mathrm{a}$ \\
POC 8 ml/1 air (P2) & $5,72(2,45) \mathrm{a}$ & $40,11 \mathrm{a}$ & $199,06 \mathrm{a}$ & $\mathrm{c}$ \\
\hline
\end{tabular}

Keterangan : Angka-angka yang diikuti oleh huruf yang sama pada kolom yang sama tidak berbeda nyata berdasarkan uji DMRT pada taraf 5\%. Angka dalam kurung adalah hasil transformasi data dengan menggunakan rumus $=\sqrt{ } \mathrm{X}+0,5$.

\section{Pembahasan}

Perlakuan pupuk organik cair pada konsentrasi $8 \mathrm{ml} / \mathrm{l}$ air menunjukkan hasil terbaik terhadap peubah pengamatan. Konsentrasi POC $8 \mathrm{ml} / \mathrm{l}$ air diduga dapat memberikan hara yang cukup untuk pertumbuhan dan hasil tanaman kentang. Pemberian pupuk organik cair dapat meningkatkan jumlah dan berat umbi kentang karena adanya penambahan unsur hara yang dibutuhkan tanaman melalui daun, selain itu juga kebutuhan hara makro dan mikro semakin terpenuhi dibandingkan tanpa pemberian pupuk organik cair.

Hasil terbaik pada perlakuan jenis mulsa didapati pada perlakuan mulsa plastik hitam perak. Lapisan berwarna perak pada jenis mulsa MPHP dapat memantulkan cahaya matahari, sehingga proses fotosintesis optimal dan dapat juga menjaga kelembaban tanah. Penggunaan mulsa MPHP efektif dalam menurunkan suhu tanah pada siang hari dibandingkan dengan tanpa penggunaan mulsa, dan efektif juga dalam mempertahankan kelembaban tanah sehingga dapat mempengaruhi pertumbuhan tanaman (Nugraha et al., 2014). Penggunaan jenis mulsa MPHP dapat memberikan pertumbuhan luas daun, indeks luas daun dan laju pertumbuhan tanaman yang lebih baik jika dibandingkan tanpa penggunaan mulsa (Prayitno et al., 2020). Warna perak jenis mulsa MPHP yang memantulkan cahaya matahari menyebabkan proses fotosintesis menjadi lebih optimal (Hidayat et al., 2018). Tanaman kentang yang memilik daun yang banyak dan besar akan menyebabkan pertumbuhannya menjadi lebih baik sehingga akan menghasilkan jumlah umbi yang lebih besar dan banyak (Prayoga et al., 2016).

Penggunaan mulsa plastik maupun mulsa kulit biji kopi dapat menyebabkan suhu dan kelembaban tanah menjadi lebih stabil. Hal ini sesuai dengan pendapat (Nugraha et al., 2014) bahwa penggunaan 
Jurnal Agrium

online version: https://ojs.unimal.ac.id/index.php/agrium P-ISSN 1829-9288. E-ISSN 2655-1837

mulsa efektif dalam menurunkan suhu tanah pada siang hari dibandingkan dengan tanpa mulsa serta efektif dalam mempertahankan kelembaban tanah sehingga akan menekan pertumbuhan gulma.

\section{KESIMPULAN}

Perlakuan mulsa berpengaruh terhadap peubah tinggi tanaman 3 MST dan 9 MST, jumlah umbi per plot, berat umbi per sampel dan berat umbi per plot.

\section{DAFTAR PUSTAKA}

Asandhi, A.A., dan Gunadi, N. 2006. Syarat Tumbuh Tanaman Kentang. Dalam Buku Tahunan Hortikultura, Seri: Tanaman Sayuran. Direktorat Jenderal Tanaman Pangan dan Hortikultura. Jakarta.

[BPS] Badan Pusat Statistik. 2021. Kependudukan Indonesia. https://www.bps.go.id/\#: : text=BPS $\% 3 \mathrm{~A} \% 20270 \% 2 \mathrm{C} 20 \% 20 \mathrm{juta} \% 20 \mathrm{Pen}$ duduk,mewujudkan\%20Satu\%20Data $\% 20$ Kependudukan \%20Indonesia. Diakses 21 Maret 2021.

Diniyah, N., Maryanto., A. Nafi., D. Sulistia., A. Subagio. 2013. Ekstraksi dan Krakterisasi Polisakarida Larut Air dari Kulit Kopi Varietas Arabika (Coffea arabica) dan Robusta (Coffea canephora), Jurnal Teknologi Pertanian, 14 (2),73-78.

Direktorat Jenderal Perkebunan Departemen Pertanian, 2006. Statistik Perkebunan. Ditjen Perkebunan Departemen Pertanian. Jakarta.

Doring T., Heimbach, U., Thieme, T., Finckch, M., dan Saucke, H. 2006. Aspect of straw mulching in organic potatoes-I, effect on microclimate, Phytopthora infestans, and Rhizoctonia solani. Nachrichtenbl. Deut. Pflanzenschutzd, 58 (3),73-78.
Maret, 2021

Vol. 18, Nol

Hal. 80-87

Author(s): Ismadi, et al

Perlakuan mulsa terbaik didapatkan dari penggunaan mulsa plastik hitam perak. Perlakuan pupuk organik cair berpengaruh terhadap jumlah umbi per sampel, jumlah umbi per plot dan berat umbi per sampel. Konsentrasi terbaik didapatkan dari penggunaan pupuk organik cair $8 \mathrm{ml} / 1$ air. Tidak terdapat interaksi antara perlakuan jenis mulsa dan pupuk organik cair terhadap pertumbuhan dan hasil tanaman kentang.

Hidayat, Y.S., Efendi, D., dan Sulassih. 2018. Karakterisasi Morfologi Beberapa Genotipe Kentang (Solanum tuberosum L.) yang dibudidayakan di Indonesia. Comm. Horticulturae J. 2(1), 28-34

Kementrian Pertanian Republik Indonesia. 2020. Data Lima Tahun Terakhir Sub-sektor Hortikultura (Horticulture Sub-sector), https://www.pertanian.go.id/home/?sh ow=page\&act $=$ view\&id $=61$. Diakses 19 Maret 2021.

Nugraha, M.W., Sumarni, T. dan Suryanto, A. 2014. Penggunaan Ajir dan Mulsa untuk Meningkatkan Produksi Kentang (Solanum tuberosum L.) Varietas Granola. Jurnal Produksi Tanaman, 2(8), 640-648.

Mahmood, M., Farroq, K., Hussain, A., Sher, R. 2002. Effect of mulching on growth and yield of potato crop. Asian J. Of Plant Sci, 1(2),122-133.

Parman, S. 2007. Pengaruh Pemberian Pupuk Organik Cair terhadap Pertumbuhan dan Produksi Kentang (Solanum tuberosum L.). Buletin Anatomi dan Fisiologi Tanaman, 15(2).

PrayitnSo, M.F dan Suryanto A. 2020. Intersepsi Radiasi Matahari pada Berbagai Macam Mulsa terhadap 
Pertumbuhan dan Hasil Tanaman Kentang (Solanum tuberosum L.) Varietas Granola. Universitas Brawijaya, Jurnal Produksi Tanaman, 8(5).

Prayoga, K. M., Maghfoer, M. D. dan Suryanto, A. 2016. Kajian Penggunaan

Mulsa Plastik dan Tiga Generasi Umbi Bibit yang Berbeda pada Komoditas

Kentang (Solanum tuberosum L.) Varietas Granola. Jurnal Produksi Tanaman, 4 (2), 137-144.
Setjen Pertanian. 2019. Statistik Konsumsi Pangan 2018. http://epublikasi.setjen.pertanian.go.id lepublikasi/StatistikPertanian/2018/K onsumsi/Statistik Konsumsi Pangan Tahun 2018/files/assets/basichtml/page56.html. Diakses 22 Maret 2021.

Triyanto. R. 2000. Pembuatan dan Uji Mulsa Organik Lembaran dari Eceng Gondok (Eichhornia crassipes) (Skripsi). Jurusan Teknik Pertanian Fakultas Teknologi Pertanian, UB, Malang. 